\title{
Judging the Judges: finding value in these problematic characters
}

L R Martin

(Theological Seminary Cleveland, U S A) ${ }^{1}$

\section{ABSTRACT}

Judging the Judges: finding value in these problematic characters

The biblical judges are well known for their less than exemplary behaviour. In the past, these judges have been appreciated largely as examples of how a charismatic leader should not behave. In spite of the judges' questionable morals, the writer of the book of Hebrews commends four of them (Barak, Gideon, Jephthah, and Samson) for their faith. This paper evaluates these judges in light of their characterisations in the book of Hebrews and in the book of Judges and suggests that our struggle with the judges parallels the contemporary integrity crisis in Christian leadership.

\section{INTRODUCTION}

'Time would fail me', declares the writer of Hebrews, 'to tell of Gideon, Barak, Samson, Jephthah, of David and Samuel and the prophets-who through faith conquered kingdoms, administered justice, obtained promises, shut the mouths of lions, quenched raging fire, escaped the edge of the sword, won strength out of weakness, became mighty in war, put foreign armies to flight' (Heb 11:32-34; NRSV) ${ }^{2}$. With these words the judges of the Old Testament are forever enshrined as heroes of the faith, and consequently they have served as examples to Christian believers from the First Century until now. Careful readers of the book of Judges, however, might suggest a few changes to Hebrews 11, so that the text would read: 'Time would fail me to tell of the judges, ... who through unbelief

1 Lee Roy Martin (DTh UNISA) is Associate Professor of Old Testament and Biblical Languages at the Church of God Theological Seminary in Cleveland, TN USA and a Research Associate of UNISA, Department of Old Testament and Ancient Near Eastern Studies.

2 Unless noted otherwise, Scripture citations are my own translation. 
tested God, committed murders, pursued pleasure, enabled idolatry, and turned Israel into a land of anarchy'.

As these hypothetical changes to Hebrews show, we are faced with paradoxical depictions of the judges; for although the book of Hebrews applauds the faith of the judges, the book of Judges records the obvious flaws and failings of those same judges. Both Jephthah and Samson are particularly unfit for the designation 'heroes', given their apparently immoral character. Jephthah is an outlaw who makes a rash vow that results in the sacrifice of his daughter, and Samson is a divinely chosen nazirite who breaks his sacred vows, marries a forbidden foreigner, sleeps with a prostitute, and loses his God given power while asleep on the lap of Delilah. Interpreters from a number of traditions have questioned how it is possible for God to use these judges who seem to be morally deficient. Wolf (1992:381), for example, calls this tension a 'problem', and McCann (2002:1) admits that Judges is 'an embarrassment to most church folk'.

Pre-critical interpreters as a rule are either unwilling or unable to wrestle with the tensions presented by the judges ${ }^{3}$. One stream of the Jewish tradition, either unable or unwilling to engage the difficulties of the text, asserts that God's choosing of the judges is clear evidence of their spiritual qualifications. Scherman (2000:xiv) writes, 'The judges were chosen by God as individuals of outstanding merit'. In like manner, John Wesley, maintaining that Jephthah did not kill his daughter but only devoted her to life-time tabernacle service, furiously rebukes Matthew Henry for even entertaining the possibility that Jephthah, a chosen leader, would actually sacrifice his daughter (Wesley \& Schoenhals 1987:171). Wesley (1958 XIV:367-532) included the book of Judges in his notes on the Bible, but he apparently did not preach from Judges. Perhaps

3 On the pre-critical exegesis of Judges, see chapter 2 of Martin (2008b). Most interpreters prior to the reformation resorted to allegory and typology as the way to make sense of the judges; see Gunn (2005), who traces the reception history of the entire book of Judges. 
Wesley would have agreed with esteemed commentator C F Burney (1918:cxxi), who declares that Judges lacks 'spiritual appeal'4.

In my monograph on the book of Judges, I point out that the human characters of Judges have received the primary attention of biblical scholars while the character of Yahweh has not been sufficiently treated. I argue that considerable theological insight can be mined from Judges by paying attention to the previously unappreciated speeches of God in the book (Martin 2008b). It remains to be seen, however, if anything good can be salvaged when it comes to the actions and attitudes of the judges themselves. Biblical scholarship has doubted that the lives of Barak, Gideon, Jephthah, and Samson can offer any positive theological models for righteousness, holiness, or faithful leadership. Recent interpreters, however, have constructed a theological view of the book of Judges that promises hope for redeeming the judges from the hands of their judges (Brueggemann 1981:73-90; McCann 2002:14-20 and Birch et al 1999:181-89).

In this paper, I will examine the place of the judges within the argument of the book of Hebrews, and I will evaluate the judges as they are characterised in the narrative of Judges. I will attempt to discover the ways in which the judges may serve as positive figures, and I will suggest connections between the biblical portrait of the judges and our own integrity crisis in contemporary Christian leadership.

\section{THE ROLE OF THE JUDGES IN HEBREWS 11}

The book of Hebrews is an elaborately constructed literary masterpiece that speaks to a number of theological, ethical, and social issues that are of concern to its intended audience. Although the complexity of the book continues to defy biblical scholarship's quest for consensus regarding its purpose, the text suggests, on one level at least, that Hebrews is an encouragement to Christian faithfulness in the face of severe opposition. Baker (1997:439) writes that the purpose of Hebrews is 'to call believers to remain steadfast and to take courage' (cf Renwick 2003:300-301; Attridge

4 While pre-critical writers and holiness interpreters have struggled primarily with the personal immorality of the judges, it is the violence in Judges that offends many contemporary interpreters. 
1990:217; Lane 1988:472-75 and Ellingworth 1993:58). The nature of Hebrews as exhortation is registered in the frequency of hortatory subjunctives: 'Let us fear . . . lest anyone fall short' (4:1); 'let us strive' (4:11); 'let us hold fast to our confession' (4:14); 'let us approach with confidence' (4:16); 'let us go on toward perfection' (6:1); 'let us approach with a true heart' (10:22); 'let us hold fast' (10:23); 'let us consider one another' (10:24); 'let us lay aside every weight . . . and let us run the race' (12:1); and so forth. Christian believers are enjoined to hold fast, to run their race patiently, and to encourage each other, because Christianity is the better way. Christ is better than the angels (1:4), better than Moses (3:3), better than Joshua (4:8), and better than the Old Testament priesthood (7:1-28). Christians have a better hope (7:19), based on a better covenant (7:22), with better promises (8:6). They offer better sacrifices $(10: 1)$, have a better future $(10: 34)$, in a better country $(11: 16)$, because God has 'provided something better for us' (11:40).

The Christian audience of Hebrews, therefore, is enjoined to do better than the Israelites of the Old Testament; that is, they should go forward and not turn back (Heb 3:7-4:13). They are exhorted to beware, lest there be found in them an evil heart of unbelief' (3:12). They should be steadfast (3:14), unlike the Israelites in the wilderness, who heard God's word but did not have 'faith' (4:2). The audience should not fall into 'unbelief' (4:11), but should believe the living word of God (4:12), and should, in times of struggle, approach the throne of grace through Jesus, the faithful high priest (4:16).

The importance of faith to Christian perseverance, a topic introduced in chapter 3 , is revisited in chapter 10 in a text which, along with 12:1-3, serves to bracket chapter 11 with calls for steadfastness. Thus, before we are presented with the hero list of chapter 11, we hear, 'the just shall live by faith, but if he should hesitate my soul takes no pleasure in him. But we are not people of hesitation that leads to destruction, but people of faith that leads to the preserving of the soul' (10:38-39). Although the genitives

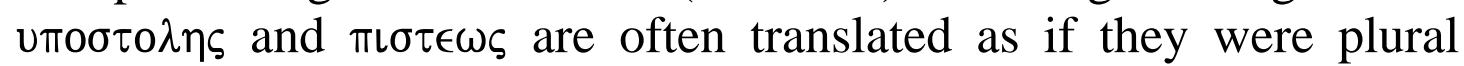
participles (e g 'we are not of those who shrink back . . . but of those who believe' [NIV]), they are in fact singular nouns, translated literally, 'we are not of hesitation . . . but of faith'. As genitives of relationship, their function is to describe the subject and could be paraphrased, 'we are not characterised by hesitation . . . but by faith'. This faithful endurance is then exemplified in the biblical characters 
who are presented in Hebrews 11. The kind of faith practiced by these Old Testament believers is more than saving faith (Baker 1997:440); it is 'persevering faith' (Baugh 2006:119); it is 'active' faith (Baker:1997:440) . By faith they obey God; by faith they overcome insurmountable odds; by faith they continue walking with God when contextual forces stand in opposition to his promises (cf Cosby 1988b:258-61 and 1988a:41-55).

Regarding the function of Hebrews 11, Baugh argues that the heroes are not so much examples whose faith 'we are to emulate' as they are 'recipients of divine testimony to the coming eschatological realities, and thence by faith they became participants in and witnesses to the world to come' (2006:113). Although I am unconvinced of Baugh's primary thesis, he offers a number of helpful observations. For example, he argues for the cruciality of the repeated motif of seeing the unseen (2006:121-22), a motif that I also emphasised when I suggested that the faith of Hebrews 11 can 'See the Invisible', 'Obey the Incomprehensible', 'Accomplish the Impossible', and 'Endure the Intolerable' (Martin 1996). Baugh's argument is weakened by the fact that he limits his detailed study to only Abel, Enoch, Noah, and Abraham. I would argue that even though the heroes of chapter 11 are 'witnesses' (Baugh 2006:118-21) to God's faithfulness and are examples of endurance, the most important example is Jesus himself (cf Rhee 1998:274-75). Following the list of prominent Old Testament characters, we hear another call to perseverance, 'Therefore, let us run with endurance the race that is set before us, looking unto Jesus the founder and perfecter of faith; . . . consider him lest you grow weary and lose heart' (12:1-3).

Hebrews 11 is both preceded by and followed by references to endurance, a contextual factor that is recognised by Culpepper (1985:375-80) and Eisenbaum (1997:137), but which is not

5 Discussions regarding the Christian content of faith within the epistle are not directly germane to my argument; nevertheless, cf Cosby (1988a:34-40);

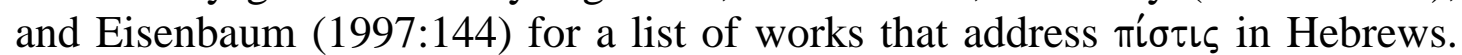
Eisenbaum (1997:144) agrees with the leading view (as do I) that 'Hebrews is continuous with the Jewish understanding of faith as fidelity, firmness, and trust in God', a view that in my mind does not exclude Jesus as the object of saving faith for NT believers. So also, Rhee (2000:93). 
appreciated by Brawley (1993:81-98), whose emphasis ironically is on the context of Hebrews 11. Cosby (1988a:40, 85-89) notes the introductory function of 10:35-39 but does not observe the concluding function of 12:1-3. This bracketing of Hebrews 11 with exhortations to steadfastness suggests that the function of chapter 11 is to give hope to those who are struggling, by demonstrating the genuine possibility of faithful endurance. Furthermore, in Hebrews 11, 'faith and hope are immediately linked', declares Baker (1997:440). Dautzenberg (1973:167-68) goes so far as to assert that in Hebrews, faith and hope are interchangeable. These Old Testament characters persevered in hope; they ran faithfully 'on the same field, in the same arena of life, in the name of the same God, as the present readers' (Renwick 2003:300). Assurance is desperately needed by the intended hearers, argues Renwick, who writes, 'Their strength had been so sapped that the community as a whole could not help its members meet their present difficulties with any enthusiasm, let alone with any longing to persevere' (2003:300).

Both of the bracketing texts contain the word 'faith' (Heb $10: 38,39 ; 12: 2)$. Thus, the writer of Hebrews argues that the just shall live by faith and that the hearers are people of faith (10:38-39). This faith is exemplified in the heroes of the Old Testament (11:140), but Jesus is the greatest example. In fact, he is more than an example; he is the founder and perfecter of faith (12:2).

Having established that at least one purpose of the hero list of Hebrews 11 is to offer hope and encouragement to the hearers of the epistle, let us now examine the place of the four judges within the list. The hero list begins with Abel and proceeds to name Enoch, Noah, Abraham, Sarah, Isaac, Jacob, Joseph, Moses’ parents, Moses, the Israelites, and Rahab in chronological order. In each case, at least one event from the life of the hero is presented as an example of trust in the promises of God. At verse 32, however, the writer expresses a need to conserve time, and the pattern of reportage changes (cf Cosby 1988a:57-71). The faith of the judges, David, and the prophets is described in general terms, without reference to specific events and out of sequence chronologically. Commendation of the judges, David, Samuel, and the prophets is given for the following praiseworthy actions: they 'conquered kingdoms, administered justice, obtained promises, shut the mouths of lions, quenched raging fire, escaped the edge of the sword, won strength out of weakness, became mighty in war, put foreign armies to flight' 
(Heb 11:33-34; NRSV). For the purposes of this paper, we need not connect each action to a particular Old Testament figure, but we should consider a few general observations: 1 . All of these actions are interpreted by the writer as expressions of faith, even though the word 'faith' is not found in the book of Judges'; 2. All of these actions are related closely to strength and victory in warfare, except for the four phrases in the middle of the list ('administered justice, obtained promises, shut the mouths of lions, quenched raging fire'); 3. The phrase 'obtained promises' is a motif that is prominent in Hebrews (the Greek word ' $\epsilon \pi \alpha \gamma \in \lambda^{\prime} i \alpha$ is found 14 times in the book: $4: 1 ; 6: 12,15,17 ; 7: 6 ; 8: 6 ; 9: 15 ; 10: 36 ; 11: 9,13,17,33,39)$; 4. The phrases, 'shut the mouths of lions' and 'quenched raging fire', suggest escape from dangers that may not be directly related to warfare; 5 . None of the actions relate to moral virtues, unless we

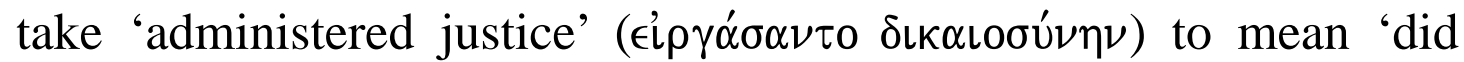
what was right' (cf Bauer 2001), but which, coming after 'conquered kingdoms', more likely means that they restored order and justice after vanquishing enemy forces. Surprisingly, the Greek phrases in Heb 11:32-34 have no verbal parallels in the LXX. Words like 'lion', 'righteousness', 'fire', 'sword', and 'armies' are found in the OT, but not in combination with the verbs used in Hebrews 11.

Therefore, we might observe that in Hebrews 11 the judges are not commended for their holiness, compassion, generosity, meekness, or self-control; a fact, however, that should not detract from the numerous ethical injunctions in Hebrews, including for example, 'Pursue peace with everyone, and holiness without which

6 On the hermeneutics of the writer of Hebrews, see Johnson (2003:23750). See also Eisenbaum (1997:89-134), who argues that, as a reinterpretation of Jewish history for a Christian audience, Heb 11 displays these attributes: 1. Heb 11 removes the nationalism from the OT story; 2. The exploits of the characters in Heb 11 are diminished so that their fame will not challenge that of Jesus; and 3. Characters in Heb 11 are praised for actions that differ from the actions for which they are praised in the OT. Eisenbaum's is a helpful study, but her selective use and misinterpretation of evidence make her conclusions applicable only to a few of the persons named in Heb 11, while her arguments are unconvincing when applied to the whole list. Bruce (1964:318-21) explicates what he considers to be evidence of faith in Barak, Gideon, Jephthah, and Samson. However, my purpose in this paper is not to show explicit correspondence between Hebrews and Judges. 
no one will see the Lord' (12:14). The lack of attention to moral issues is not surprising when we compare the writer's treatment of the other Old Testament heroes. In fact, none of the heroes of Hebrews 11 are praised for their moral purity and few are presented in the Old Testament as blameless. Of all the characters in Hebrews 11, only Abel, Enoch, and Moses' parents are without fault in the Old Testament narrative. Noah begins well, but then succumbs to drunkenness and ends up cursing his son. Abraham's life is a series of ups and downs, checkered with lies and doubts. When Sarah hears God's promise, she laughs incredulously. Moses is a murderer; Rahab is a prostitute; David is an adulterer and a premeditated murderer. By faith the Israelites passed through the Red Sea (Heb 11:29), but the next day they grumbled against Moses (Ex 15:24). By faith the walls of Jericho fell down (Heb 11:30); but in their next battle, the Israelites were soundly defeated because of disobedience (Jos 7:1-15). Samuel was nearly perfect, but he failed in the end by installing his unscrupulous and immoral sons as judges (1 Sm 8:1-4). As examples of endurance, therefore, the Old Testament characters are acceptable; but as an example of victory over sin, only Jesus is sufficient (Heb 4:15).

The book of Hebrews, by highlighting the positive qualities of Old Testament characters, provides examples of heroic acts that are worthy of appreciation and emulation. In spite of their sins the heroes of Hebrews 11 embraced the promises of God and pressed forward beyond their encumbering circumstances and their personal flaws. Nevertheless, I contend that the inclusion of the judges in the list of heroes is not a blanket approval of their every act; it does not exonerate them from their crimes. The book of Hebrews maintains a critical tension that many interpreters have failed to let stand (cf Gunn 2005:134, 169, 171).

We could expand the conversation to include famous leaders throughout Christian history. The divisive argument between Barnabas and Paul in Acts 15 does not erase their praiseworthy and sacrificial accomplishments of the previous chapters. The hypocrisy of Peter (Gl 2:11) does not diminish his role in the inclusion of the Gentile believers (Ac 10-11). Martin Luther's anti-Semitism does not eliminate his courage and steadfastness in leading the Reformation; and the smoke that arises from the burning of Michael Servetus does not blot out the light that shines from John Calvin's commentaries. 
Although the writer of Hebrews does not choose to point out the failures of the Old Testament characters, those failures are not ignored in the Old Testament and they would be well-known by the intended audience of the book of Hebrews. The Old Testament, by showing both the positive and negative qualities of its characters, is able to utilise these characters in complex and realistic events that register a variety of subtle theological messages. The book of Judges, as narrative, is able to paint a picture of the judges that is more holistic than is possible within the confines of an epistle (cf Martin 2008b). Hebrews, therefore, focuses only on the positive characteristics of the judges that might encourage the early Christians to endure faithfully.

Popular character studies have downplayed the flaws of the judges (Gunn 2005:106-109); but in spite of its commendation of the judges, Hebrews 11 does not provide justification to disregard the moral and ethical problems that are reflected in the book of Judges. For example, it is not legitimate for us to assume, on the basis of his presence in Hebrews 11, that Jephthah would not have sacrificed his daughter. Nevertheless, the inclusion of the judges among the heroes of faith suggests that our search for something of value in these problematic characters is canonically legitimate. It might be argued that Hebrews 11 has already identified the value of the judges-their value is in their faith. Such an argument has merit; but as I pointed out above, the writer of Hebrews characterises the judges in a way that advances the argument of Hebrews. I hope to discern the value of the judges as they are portrayed in the book of Judges. I accept, with some limitations, the contention of Waddell (2006:78) that the intertextual reading of an interpretive text (Hebrews) will cause us to reconsider and revise our readings of the interpreted text (Judges). We move now to the book of Judges.

\section{THE ROLE OF THE JUDGES IN THE BOOK OF JUDGES}

The judges do not appear in a vacuum; rather, they emerge as characters with the narrative of the book of Judges. Consequently, I would argue that the value of the judges must be discerned in light of their place in the narrative and message of the book of Judges. The judges are mentioned first in the prologue of the book (2:6-3:6), which outlines the cyclical framework for the series of stories to come in chapters 3-16. The cycle begins when the Israelites forget Yahweh and engage in idolatry. The behaviour of the Israelites 
provokes Yahweh to anger, and he disciplines them by handing them over to an oppressive enemy. The Israelites then cry out to Yahweh for deliverance, and Yahweh is moved with compassion because of their suffering. Finally, Yahweh raises up a judge who saves the Israelites from their enemy, and the land enjoys a time of peace. Although each appearance of the cycle incorporates a unique combination of elements, variations that are charted in detail by O'Connell (1996:22-25), the cycle can be reduced to two basic movements. First, the Israelites rebel and God punishes them; and second, the Israelites cry to God and he saves them (cf Beyerlin 1963:1-29; Brueggemann 1981:73-90). Both of these movements hinge on the responsiveness of Yahweh, who acts out of both judgment (sin/punishment) and mercy (cry/salvation) to preserve his covenant relationship to Israel.

Although the actions of the judges relate on the surface to the second movement of the cycle (cry and salvation), at a symbolic level the lives of the judges intersect with the first movement (sin and punishment) as well. That is, the sin of Israel is reflected in the flaws of the judges. This symbolism develops out of the perspective toward Israel's sin that is conveyed by the book of Judges. The besetting sin of the Israelites is breaking the covenant, forsaking Yahweh, and worshiping foreign gods-in a word: idolatry. Furthermore, the book of Judges presents Yahweh's relationship to his people in corporate terms. The book of Judges uses the term ישְרָה

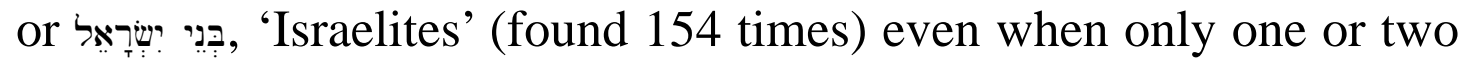
tribes are in view. For example, Abimelech rules Shechem only, but the narrative says he 'ruled Israel' (9:22), and Jephthah leads Gilead alone, but the text says he 'judged Israel' (12:7). Although the judges and their battles may be limited in scope, the narrative (by using 'Israelites') invests each episode with national significance, a feature observed as well by G von Rad (1962:331-32), Gottwald (1979:149), Kaswalder (1993:89), and Goldingay (2003:531-33). Because the covenant with Yahweh is a corporate matter, the unfaithfulness of the Israelites incurs Yahweh's punishment of the entire people; and the cries of the Israelites elicit Yahweh's compassion toward the entire body.

The unfaithful behavior of the Israelites grows worse throughout Judges (2:19); suggesting that the repeated pattern is more than a cyclical repetition; it is a downward spiral (Lilley 1967:98-99). This corporate downward spiral into unfettered idolatry 
is paralleled in the narrative by the problematic behaviour of the judges themselves. The increasingly negative characterisation of the judges mirrors the increasingly disobedient character of the Israelites and the overall spiritual decline within the book (Martin 2008b; Exum 1990:410-31). Othniel is the ideal judge, a mighty warrior, who saves Israel from the oppressive king Cushan-rishathaim (3:711). The progression from the ideal (Othniel) to the worst of the judges (Samson) begins subtly with the second judge Ehud, who has no major flaws; but his left-handedness makes him less than ideal (3:15). Deborah is also without fault, but her gender may have presented her with distinct challenges in the male-dominated society. Barak is the first judge to show a hint of weakness (4:6), when he hesitates to follow the instructions of Deborah (cf Gunn 2005:6869). Gideon, the next judge, is a full-fledged coward (6:27), who requires repeated assurances from God and who unwittingly leads Israel back into idolatry (8:27). Jephthah, the son of a prostitute, is an outcast from society who is chosen not by God, but by the elders of Gilead. Jephthah foolishly vows to offer up as a whole burnt offering the first person (or thing) who comes out to greet him on his safe return from battle (11:30-31). Jephthah saves the Israelites from only one of the two nations who threaten the Israelites (10:7), thus being the first judge who fails to bring complete deliverance. Finally, Samson does not save Israel at all; he only 'begin[s] to save' them from the Philistines (13:5) through the limited impact of his brief skirmishes. Samson is the only judge who is unable to raise an army of Israelites and inspire a rebellion against their oppressor, and he is the only judge who is captured by the enemy. The story of Samson, however, ends with a ray of hope, as he cries out to Yahweh who restores his strength, enabling him to destroy the temple of Dagon, thus striking at the very heart of the enemy's god (cf Webb 1987:167; Greenstein 1981:252). In spite of Samson's final individual effort, however, the downward spiral is complete, and the Israelites are content to live under the domination of the Philistines $(15: 11)$. Samson serves as a paradigmatic figure, whose feeble response to divine gifting represents the inability of all Israel to remain loyal to the covenant. The story of Samson, therefore, represents the story of Israel (Greenstein 1981:237-60). At the end of Judges anarchy and immorality reign supreme, and the Israelites do as they please because there is no king - neither human nor divinein Israel (17:6; 18:1; 19:1; 21:25). 
The foregoing sketch of Judges suggests that the flaws of Barak, Gideon, Jephthah, and Samson are essential to the theological message of the book of Judges and carry a significant spiritual warning. The increasingly problematic character of the judges parallels the increasingly disobedient character of the Israelites. If the writer of Judges had chosen to downplay the failures of these final judges, the narrative impact of the book would have been greatly diminished. The sin of the judges, in conjunction with the sin of Israel, registers a valuable spiritual message, though a negative one.

A more positive role for the judges is their participation in the second movement of the cycle-cry and salvation. In Judges the Israelites violate their covenant with Yahweh by pursuing other gods, thereby provoking the wrath of Yahweh, who gives his people over to an enemy power. These enemies are the Canaanite city-states, small kingdoms that are ruled by autocratic monarchs, who dispense tyranny from within fortified cities. Many of these kings and their city-states are listed among the conquests of Joshua (Jos 12). Like the Egyptians, the Canaanites represent oppressive forces that undermine the liberating nature of the Mosaic covenant. In the Canaanite system, the gods are an integral part of the royal power structure, bound to the king and his ruling elite. In the Mosaic covenant, however, God is free and stands as judge over the political structure. In the Canaanite system, human rights are afforded only to the wealthy landowners; but in the Mosaic covenant, even the poor, the widow, the orphan, and the alien are given human rights. McCann argues that the Canaanites symbolise the 'ways of organising social life that perpetuate injustice and ultimately produce oppressive inequalities that threaten human life' (McCann 2002:19).

The suffering of the oppressed Israelites is portrayed vividly in the accounts of Judges. King Jabin of Hazor, the enemy in the Barak story, 'mightily oppressed' the Israelites for twenty years (Jdg 4:3). The Philistines and the Ammonites, the foes of Jephthah, 'vexed and oppressed the Israelites eighteen years' and the Israelites were 'sore distressed' (10:8-9). It is said that the Philistines, against whom Samson struggled, ruled over the Israelites forty years (13:1). The most extensive description of Israel's suffering is found in chapter 6 , where the violence of the Midianites is described:

The hand of Midian prevailed over Israel; and because of Midian the Israelites provided for themselves hiding 
places in the mountains, caves and strongholds. For whenever the Israelites put in seed, the Midianites and the Amalekites and the people of the east would come up against them. They would encamp against them and destroy the produce of the land, as far as the neighborhood of Gaza, and leave no sustenance in Israel, and no sheep or ox or donkey. For they and their livestock would come up, and they would even bring their tents, as thick as locusts; neither they nor their camels could be counted; so they wasted the land as they came in. Thus Israel was greatly impoverished because of Midian; and the Israelites cried out to the LORD for help (Jdg 6:2-5; NRSV).

Once in bondage to these oppressive forces, the Israelites 'cannot evade the superior power, and their powers of resistance are inadequate. The force that is oppressing or threatening the people, the attacking enemy, is simply stronger' (Welker 1994:52). Jabin, for example, has iron chariots (4:3), and the Midianites have a vast army riding on camels (6:5).

Under the burden of tyranny and in the face of hopelessness, Gideon laments, 'where are the wonders that our ancestors recounted to us?' (6:13). The Israelites cry out to Yahweh, and he hears their cries and is moved with compassion. Yahweh's response belongs to the paradigm of the exodus in which Yahweh reveals himself as Israel's saviour, and to the Mosaic covenant in which he reveals himself as Israel's king, her suzerain, who guarantees freedom from the human structures of authority that seek to dominate and enslave. The exodus, Israel's paradigmatic story of salvation, is mentioned in nine verses of Judges $(2: 1,12 ; 6: 8,9,13 ; 10: 11 ; 11: 13,16$ and 19:30) and seems to be in the background of Judges 5:5 and 21. Yahweh, therefore, is a new kind of Ancient Near Eastern God who is not bound to human political systems and, therefore, is not beholden to human centers of power. Yahweh is the God who is free to bestow his saving power upon whomsoever he will, who is faithful to his covenant people, who passionately embraces those who suffer, and who suffers with them. Because of his covenant loyalty, Yahweh determines to deliver Israel from the oppressive powers of the Canaanites.

When Yahweh decides to move on behalf of Israel, he 'raises up' (2:16; 3:9; 3:15; etc.) judges who will mobilise the people and 
lead them to freedom from bondage. Yahweh recruits human partners who serve in an active role of leadership, human partners who 'succeed in restoring loyalty, solidarity, and the capacity for communal action among the people' (Welker 1994:53). In spite of their weaknesses, even the most troubling of the judges are able to accomplish amazing and inspiring deeds as they pursue salvation and justice for their communities. The judges, therefore, are more than a reflection of the spiraling decline of Israel's relationship to Yahweh; they are active participants in God's work of salvation. As human agents who are raised up by Yahweh to bring deliverance to the Israelites, the judges register Yahweh's response to the Israelites' cries for help and his intervention on their behalf (Martin 2008a).

The ministry of the judges, therefore, witnesses to the 'important role of human agency in partnership with the redeeming activity of God' (Birch et al 1999:122). In this role the judges are called 'saviours' (3:9; 3:15), who 'save' Israel (2:16; 3:9; 3:31; 6:14; 10:1; and 13:5). These saviours, however, do not act alone; they are Spirit-empowered leaders who challenge the community to action. At the behest of Deborah, Barak gathers a fighting force of 10,000 men. The Spirit of Yahweh clothes Gideon who subsequently sounds the trumpet and assembles an army (6:34). The Spirit of Yahweh comes upon Jephthah who travels throughout the region, calling the people together for battle. The judges are able to create a 'renewal of the people's unanimity and capacity for action, a renewal of the people's power of resistance in the midst of universal despair' (Welker 1994:53). What is commendable in the judges is their willingness to surrender themselves to God and to his saving mission, even when striving against overwhelming opposition. The judges respond in obedience to God's call; and with God's promise as their only assurance, they place themselves at risk in the battle to deliver Israel.

Theologically, the battle of the judges against the Canaanites represents resistance to oppression and life-negating forces of evil. The judges encourage us to pursue God's continuing mission of liberation, equality, justice, and peace (cf Isa. 11). The stories of the judges compel us to participate enthusiastically and sacrificially in God's work of salvation. The mission of the judges is not far from that of Jesus the Messiah, who declared, 'The Spirit of the Lord is upon me, because he has anointed me to bring good news to the 
poor. He has sent me to proclaim release to the captives and recovery of sight to the blind, to let the oppressed go free' (Lk 4:18; NRSV) ${ }^{7}$.

While I am arguing that the primary spiritual value of the judges is to be found in their dedication to God's mission of deliverance, I would suggest as well that the charismatic nature of their leadership continues to offer an important model for the Church. The Old Testament people of Israel existed under two primary models of organisation-tribal leadership and monarchy. Each of these paradigms has distinct benefits and clear drawbacks, and we could argue for the advantage of one over the other. While it is true that charismatic leadership finds more acceptance within egalitarian tribal organisation than within hierarchical structures, the biblical narrative seems to bear witness to the value of charismatic leadership as a continuing element in the government of God's people. A vast literature has developed around the sociology of charismatic leadership; and while I appreciate the insights of sociology, I would argue that sociological studies do not account for the theological content of the biblical model of charismatic leadership (cf Willis 1997:33-44; Malamat 1996:293-310; Munch 1990:57-69; and Weisman 1977:399-411). Pre-monarchic Israel is structured around tribes, elders, and local chieftains; and although God often chooses to utilise established leaders (e g, Nm 11:16; Jdg 3:9), he also raises up leaders who held no previously recognised authority (Jdg 6:11; 11:1-11). Once Israel becomes a centralised monarchy, the entire social structure is reordered; and the king has power to authorise, commission, and empower leaders. Even under the monarchy, however, God continues to raise up charismatic leaders, leaders who do not come to their position by inheritance,

7 It is not that we have lost our will to fight, but that we, like the Israelites at the end of Judges, fight among ourselves rather than fighting against the oppressor. We fight over ecclesiastical politics; we fight over budgets; we fight over recognition; we fight over personal rights; we fight over fine points of theology; we fight over denominational pride. Our energy is expended by internal strife, so that we have no strength to fight for the weak, the poor, and the disenfranchised. If the Church serves Baal, who then is left to offer hope to the alcoholic, the drug addict, the prostitute, the pornographer, the laid-off factory worker, the abandoned child, the widow, and the single mother? 
leaders who do not arrive through political campaigns, leaders who do not gain their positions through violent overthrow of their predecessors, leaders who are raised up by God, authorised and empowered by the Spirit of God. The first kings of Israel, Saul and David, were themselves charismatic leaders, but most of the charismatics in the monarchic period are prophets.

The history of the church is in part a struggle for a biblical system of ecclesial polity that is just, equitable, and effective in governing the Church and in facilitating the Church's mission. If the contemporary Church is to face the challenges of globalisation and post modernity, it must retain the biblical appreciation for charismatic leadership.

\section{THE JUDGES ARE AMONG US}

I have shown that due to the tension between Hebrews 11 and the book of Judges we have struggled to find an appropriate interpretation of and response to the judges. On the one hand, the judges can be helpful as examples of charismatic leaders who devote themselves to the saving mission of God; on the other hand, their reputations are stained by moral flaws. I would suggest that our struggle with the judges parallels in some ways the contemporary integrity crisis in Christian leadership. The contemporary Church is mired in a culture that is unable to deal effectively with issues of discipline. We are correct to hold our leaders to a high moral standard, but in so doing we have unwittingly created an idealised view of leadership, which tends to follow one of two extremes. Either ministers are not held accountable for their sins because it is believed that the 'success' of their ministry is proof that they are in good standing with God; or ministers are forced out of their pastorates because of sins that might demand disciplinary action, but which should not disqualify the person for ministry (assuming, of course, that the person is willing to submit to discipline). Either we refuse to require accountability for moral failings (even when the person is convicted for criminal behaviour), or we demonise any leader who is suspected of a moral lapse.

It is clear that the endowment of the Spirit does not grant infallibility to humans. It is also clear that Spirit-filled leaders should not be immune from the demands of biblical holiness. Barak is celebrated for his victory, but he is rebuked for his hesitancy (Jdg 4:9). Gideon is praised for leading 300 brave soldiers against a 
mighty army of Midianites, but he is reprimanded for constructing a golden ephod (Jdg 8:27) ${ }^{8}$. I am not suggesting that the Church should use the Old Testament as the primary resource for the development of a theology of leadership, but I am suggesting that our uncertain response to the judges is symptomatic of our uncertain response to contemporary leadership failure. In a nutshell, when leaders fail, the Church does not know what to do!

\section{CONCLUSION}

The positive representation of the judges in Hebrews 11 must not be seen as a blanket endorsement of their lives and character, but neither should the Old Testament's portrayal of the negative qualities of the judges cause us to doubt the appropriateness of the judges inclusion in Hebrews 11. Pre-critical interpreters, who come to the text with a predisposed sympathy toward biblical characters, tend to be unable or unwilling to wrestle with difficult texts that expose the spiritual inadequacies of those characters. Thus, pre-critical commentators often minimise the undesirable aspects of Old Testament characters while focusing upon their heroic traits. Critical interpreters, however, with no vested interest in defending the biblical characters, often highlight their shortcomings and flaws. I would argue that neither approach fully appreciates the richly textured portrayals of the biblical characters and neither does justice to the biblical text as narrative theology. And although I would by no means exonerate the judges, I would suggest that they might be no more sinful than other biblical characters, such as the venerable David, who commits adultery and premeditated murder, motivated solely by self interest.

We find similar inappropriate polarising responses when faced with contemporary leadership failures. Church leaders who stumble are either demonised as worthless hypocrites or their sins are minimized through the uncritical use of the clichés: 'nobody's perfect' or 's/he is only human'. On the one hand, even a small error can lead to complete ruin, or on the other hand, a gross moral failure can result in no more than a brief embarrassment, depending upon

8 Neither Jephthah nor Samson is rebuked directly in the text of Judges, partly because their sins are obvious and partly because God withdraws and does not speak. See Martin (2008a). 
the prevalent mood of the public. Unfortunately, genuine dialog, reflection, and discernment are rarely employed as responses to leadership transgressions.

The contemporary Church, much like Israel, is tempted to accommodate itself to the dominant culture, to be seduced by the idols of the powerful, and to abandon God's mission of salvation for the poor and oppressed. In many places, the Church itself is in bondage to the Canaanites. Like Israel, the Church has settled down with the Canaanites, intermarried with the Canaanites, and served the gods of the Canaanites (Jdg 3:5-6). The stories of the Judges suggests that the Church should cry out to God for deliverance, trusting that he will raise up Spirit-filled leaders who will sound a call that mobilises the Church to repentance, renewal, and mission.

\section{Consulted literature}

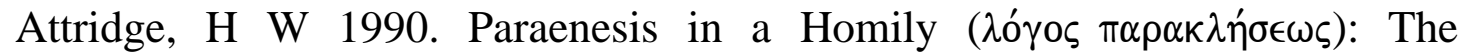
Possible Location of, and Socialization in, the 'Epistle to the Hebrews'. Semeia 50, 211-26.

Baker, K F 1997. Hebrews 11 - The Promise of Faith. Review \& Expositor 94, 439-445.

Bauer, W (BAGD) et al 2001. A Greek-English Lexicon of the New Testament, and other Early Christian Literature. Chicago: University of Chicago Press.

Baugh, S M 2006. The Cloud of Witnesses in Hebrews 11. Westminster Theological Journal 68, 113-132.

Beyerlin, W 1963. Gattung und Herkunft des Rahmens im Richterbuch, in Würthwein, E \& Kaiser, O (eds), Tradition und Situation: Studien zur alttestamentlichen Prophetie. Artur Weiser zum 70 Geburtstag, Göttingen: Vandenhoeck \& Ruprecht, 1-29.

Birch, B C, et al 1999. A Theological Introduction to the Old Testament. Nashville: Abingdon.

Brawley, R L 1993. Discoursive Structure and the Unseen in Hebrews 2:8 and 11:1: A Neglected Aspect of the Context. Catholic Biblical Quarterly 55, 81-98.

Bruce, F F 1964. The Epistle to the Hebrews. Grand Rapids: W B Eerdmans (New International Commentary on the New Testament 58).

Brueggemann, W 1981. Social Criticism and Social Vision in the Deuteronomic Formula of the Judges, in Miller, P D (ed), A Social Reading of the Old Testament: Prophetic Approaches to Israel's Communal Life, Minneapolis, MN: Fortress, 72-90.

Burney, C F 1918. The Book of Judges, with Introduction and Notes. London: Rivingtons. 
Cosby, M R 1988a. The Rhetorical Composition and Function of Hebrews 11: In Light of Example Lists in Antiquity. Macon, GA: Mercer University Press.

-, 1988b. The Rhetorical Composition of Hebrews 11. Journal of Biblical Literature 107, 257-273.

Culpepper, R A 1985. A Superior Faith: Hebrews 10:19-12:2. Review \& Expositor 82, 375-390.

Dautzenberg, G 1973. Der Glaube im Hebräerbrief. Biblische Zeitschrift 17, $161-77$.

Eisenbaum, P M 1997. The Jewish Heroes of Christian History: Hebrews 11 in Literary Context. Atlanta, GA: Scholars Press.

Ellingworth, P 1993. The Epistle to the Hebrews: A Commentary on the Greek Text. Grand Rapids, MI: W B Eerdmans.

Exum, J C 1990. The Centre Cannot Hold: Thematic and Textual Instabilities in Judges. Catholic Biblical Quarterly 52, 410-31.

Goldingay, J 2003. Old Testament Theology: Israel's Gospel. Downers Grove, IL: InterVarsity Press.

Gottwald, N K 1979. The Tribes of Yahweh: A Sociology of the Religion of Liberated Israel, 1250-1050 BCE Maryknoll, NY: Orbis Books.

Greenstein, E L 1981. The Riddle of Samson. Prooftexts 1/3, 237-60.

Griffith, S D 2005. The Epistle to the Hebrews in Modern Interpretation. Review \& Expositor 102, 235-54.

Gunn, D M 2005. Judges. Malden, MA: Blackwell Publishing (Blackwell Bible Commentaries).

Johnson, L T 2003. The Scriptural World of Hebrews. Interpretation 57, 237 50.

Kaswalder, P A 1993. Le Tribù in Gdc 1,1-2,5 e in Gdc 4-5. Liber Annuus 43, 89-113.

Lane, W L 1988. Hebrews: A Call to Commitment. Peabody, MA: Hendrickson Publishers.

Lilley, J P U 1967. A Literary Appreciation of the Book of Judges. Tyndale Bulletin 18, 94-102.

Malamat, A 1996. Charismatic Leadership in the Book of Judges, in Community, Identity, and Ideology, Winona Lake: Eisenbrauns. (Sources for Biblical and Theological Study 6), 293-310.

Martin, L R 1996. What Faith Can Do. Unpublished Sermon, Cleveland, TN: Prospect Church of God, 28 Jan 1996.

-, 2008a. Power to Save!? The Role of the Spirit of the Lord in the Book of Judges. Journal of Pentecostal Theology 16(2), 23-55.

-, 2008b. The Unheard Voice of God: A Pentecostal Hearing of the Book of Judges. Blandford Forum, UK: Deo Publishing (JPTSup 32.) 
-, forthcoming. Tongues of Angels, Words of Prophets: Means of Divine Communication in the Book of Judges, in Land, S J, Thomas, J C, \& Moore, R D (eds), Passover, Pentecost \& Parousia: Studies in Celebration of the Life and Ministry of $R$ Hollis Gause. Blandford Forum, UK: Deo Publishing.

McCann, J C 2002. Judges. Louisville, KY: John Knox (Interpretation: A Bible Commentary for Teaching and Preaching).

Munch, P A 1990. The "Judges" of Ancient Israel: An Exploration in Charismatic Authority, in: Swatos, W (ed.), Time, Place, and Circumstance: Neo-Weberian Studies in Comparative Religious History, New York: Greenwood Press. (Contributions to the Study of Religion 24), 57-69.

OConnell, R H 1996. The Rhetoric of the Book of Judges. Leiden: E J Brill (VT Sup 63).

Renwick, D A 2003. Hebrews 11:29-12:2. Interpretation 57, 300-302.

Rhee, V 1998. Chiasm and the Concept of Faith in Hebrews 11. Bibliotheca Sacra 155, 327-345.

-, 2000. Christology and the Concept of Faith in Hebrews 5:11-6:20. Journal of the Evangelical Theological Society 43, 83-96.

Scherman, N 2000. The Prophets: Joshua/Judges. The Early Prophets with a Commentary Anthologized from the Rabbinic Writings. Artscroll; Brooklyn, NY: Mesorah Publications, 1st Rubin edn.

Von Rad, G 1962. Old Testament Theology New York: Harper.

Waddell, R 2006. The Spirit of the Book of Revelation. Blandford Forum, UK: Deo Publishing (JPTSup 30).

Webb, B G 1987. The Book of the Judges: An Integrated Reading. Sheffield: Sheffield Academic Press (JSOTSup 46).

Weisman, Z 1977. Charismatic Leaders in the Era of the Judges. Zeitschrift für die Alttestamentliche Wissenschaft 89, 399-411.

Welker, M 1994. God the Spirit. Trans J F Hoffmeyer; Minneapolis, MN: Fortress.

Wesley, J 1958. The Works of John Wesley. Grand Rapids, MI: Zondervan.

Wesley, J \& G R Schoenhals. 1987. Wesley's Notes on the Bible. Grand Rapids, MI: Francis Asbury.

Willis, T M 1997. The Nature of Jephthah's Authority. Catholic Biblical Quarterly 59, 33-44.

Wolf, H 1992. Judges, in Gaebelein, F E (ed), The Expositor's Bible Commentary. Grand Rapids, MI: Zondervan, 375-508. 